\title{
An Experimental Study on Human Hair Fiber Reinforced Concrete
}

\author{
S Kaleem A Zaidi ${ }^{1 *}$, SM Talha ${ }^{1}$, Manisha Bhati ${ }^{2}$ and Shobha Ram $^{2}$ \\ ${ }^{1}$ CES, University of Vermont Cancer Center, India \\ ${ }^{2}$ School of Engineering G B University, India
}

Received: 䉑April 02, 2018; Published: 眥 April 16, 2018

*Corresponding author: S Kaleem A Zaidi, CES, University of Vermont Cancer Center, India, Email: kaleemzaidi@rediffmail.com

\begin{abstract}
This paper present the fresh and harden property of human hair fiber reinforce concrete. From the ancient time many researcher's and investors carried out research to enhance the physical and mechanical property of concrete. Now a day's human hair is considered as a waste material and an alternative non degradable matter available in abundance at cheap coast. Present study have been under taken to study the effect of human hair on medium grade concrete on basis of comprehensive strength, effect of crack control and reduce environmental problem. Further Rise Husk Ash (RHA) is a Pozzolonic material used as cement replacement in concrete. Experiments were conducted on concrete on standard cube size with addition of various $0,0.75,1.5$ and $2.25 \%$ of human hair fiber i.e. by weight of cement and RHA with 0,5,10 15 and 20\% partial replacement of cement. This investigation demonstrated significant improvement in the properties of concrete by the addition of human hair as fiber reinforcement concrete.
\end{abstract}

Keywords: Human hair, Rice Hush ash, compressive strength of concrete, fiber reinforced concrete.

\section{Introduction}

Fiber reinforced concrete (FRC) is concrete is a well known construction material containing fibers material which increases its structural integrity it contains short discrete fiber that are uniformly distributed and randomly oriented [1]. Different types of fiber's have been used as reinforcement, since ancient time the most economic and environment friendly fiber is human hair fiber. Human hair has about $65 \%-95 \%$ of its weight is proteins, more than $32 \%$ of water, lipid pigments and other components. Chemical about $80 \%$ of human hair is formed by a protein known as Kertin [1,2], with a high grade of sulphur coming from the amino acid cysteine -which is the characteristic to distinguish it from other proteins. In general the physical properties consist of resistance to breakage is a function of the diameter of the thermal of the cortex conditions. The RHA has been used as a Pozzolonic material in cement concrete, gaining several advantages such as improvement in strength, durability, and environmental aspect related to the disposal of waste material and to reduce carbon dioxide emission [3]. A review of work done by various research discuss the utilization of RHA with concrete and there is a general consensus that the use of RHA in cement improve the properties of concrete, However some other parameters are also influences the properties of concrete like partial replacement of cement by rice husk ash, fineness of rice husk ash, chemical compensation of RHA, water cement ratio, age of concrete and type of curing [3,4]. Further there is no study were taken for containing the human hair fiber in rise husk ash concrete. Literature reviews related to human hair fiber concrete also give the insight for the concrete as fiber reinforce concrete. Most of the author reputed that optimum use of human hair fibre in concrete increase the energy absorption capacity, ductility etc $[1,2,5-7]$. The human hair fiber is also suitable and cheep easily available construction material in seismic area [1]. Hence the present research aim to the study the effect of different percentage of RHA on human hair fiber added by weight in concrete specimen and its potential benefits in enhancing the properties and load carrying capacity.

\section{Excremental Work}

Rice husk ash is a product confirming to engineering requirements in terms of physical and chemical properties. In this study the effect of RHA as a partial cement replacing material with the addition of Human hair fiber were carried out. A total of 20 
mixes were casted the production of controlled concrete at M 45 grade in 1: 1.07: 1.51 ratios. The list of different mixes is given in Table 1. Three cubes were casted for each mix in the laboratory. Cement is partially replaced by RHA in the ratio of $0,5,1015$

Table 1: List the sets of cement mixture proportions. and $20 \%$. Human hair fiber is added to the mixes in the ratio of 0 , $0.75,1.5$ and $2.25 \%$ to the weight of cement to study the 28 days compressive strength and the parametric studies were carryout out.

\begin{tabular}{|c|c|c|c|c|c|c|}
\hline Mixes & Cement $\left(\mathrm{kg} / \mathrm{m}^{3}\right)$ & RHA $\left(\mathrm{kg} / \mathrm{m}^{3}\right)$ & $\mathrm{FA}\left(\mathrm{kg} / \mathrm{m}^{3}\right)$ & $\mathrm{CA}\left(\mathrm{kg} / \mathrm{m}^{3}\right)$ & Human Hair $\left(\mathrm{kg} / \mathrm{m}^{3}\right)$ & Water $\left(\mathrm{kg} / \mathrm{m}^{3}\right)$ \\
\hline M1 & 462.5 & 0 & 598 & 1115 & 0 & 185 \\
\hline M2 & 430.8 & 31.7 & 598 & 1115 & 0 & 185 \\
\hline M3 & 399.1 & 63.4 & 598 & 1115 & 0 & 185 \\
\hline M4 & 367.4 & 95.1 & 598 & 1115 & 0 & 185 \\
\hline M5 & 335.7 & 126.8 & 598 & 1115 & 0 & 185 \\
\hline M6 & 462.5 & 0 & 598 & 1115 & 4.75 & 185 \\
\hline M7 & 430.8 & 31.7 & 598 & 1115 & 4.75 & 185 \\
\hline M8 & 399.1 & 63.4 & 598 & 1115 & 4.75 & 185 \\
\hline M9 & 367.4 & 95.1 & 598 & 1115 & 4.75 & 185 \\
\hline M10 & 335.7 & 126.8 & 598 & 1115 & 4.75 & 185 \\
\hline M11 & 462.5 & 0 & 598 & 1115 & 9.51 & 185 \\
\hline M12 & 430.8 & 31.7 & 598 & 1115 & 9.51 & 185 \\
\hline M13 & 399.1 & 63.4 & 598 & 1115 & 9.51 & 185 \\
\hline M14 & 367.4 & 95.1 & 598 & 1115 & 9.51 & 185 \\
\hline M15 & 335.7 & 126.8 & 598 & 1115 & 9.51 & 185 \\
\hline M16 & 462.5 & 0 & 598 & 1115 & 14.26 & 185 \\
\hline M17 & 430.8 & 31.7 & 598 & 1115 & 14.26 & 185 \\
\hline M18 & 399.1 & 63.4 & 598 & 1115 & 14.26 & 185 \\
\hline M19 & 367.4 & 95.1 & 598 & 1115 & 14.26 & 185 \\
\hline M20 & 335.7 & 126.8 & 598 & 1115 & 14.26 & 185 \\
\hline
\end{tabular}

Cement is a mixture of calcareous siliceous, aluminum substances and crushing the clinker of a fine powder. The oxide contains are as follows. Cao, ranges 60 to 67\%, Sio2 range from 17 to $25 \%, \mathrm{Al}_{2} \mathrm{O}_{3}$, were 3 to $8 \%, \mathrm{Fe}_{2} \mathrm{O}_{3}$ equal to 0.5 to 0.6 , and $\mathrm{MgO}$ equal to 0.1 to $0.4 \%$. The ordinary Portland cement of 43 grade was used, the initial and final setting time 45 and 225 minutes respectively, the report specific gravity was3.15 and normal consistency was 32 . The fine aggraded used for this investigation was locally procured and confirmed to grading zone II. The fine aggregate was sieved first through $4.75 \mathrm{~mm}$ sieve to remove any lumps or particles greater than $4.75 \mathrm{~mm}$ and was then washed to remove dust. The specific gravity 2.45 and fineness modulus 2.55 are used. The coarse aggregate are free from dust before being used in concrete and the specific gravity was 2.63 and fineness modulus 6.42 and the size of aggregate $20 \mathrm{~mm}$ down and retained on IS sieve No. 4.75 $\mathrm{mm}$. Waste: Waste used in the study is confirmed to IS $456-2000$ for mixing as well as curing of concrete cubes. Human Hair fiber were the different sizes ranges from 10 to $70 \mathrm{~mm}$ which was easily available from the local source. Some of the properties of human hair are given in Table 2. Rich Husk Ash: The RHA was obtained from local source the physical and chemical properties of RHA are as follows in Table $3 \& 4$ respectively.
Table 2: Properties of human hair.

\begin{tabular}{|c|c|}
\hline Properties & Value \\
\hline Length of hair fiber & 10 to $70 \mathrm{~mm}$ \\
\hline Diameter of hair & 90 to $120 \mu \mathrm{m}$ \\
\hline Aspect ratio(length of fiber/Diameter of fiber) & 111 to 700 \\
\hline Tensile strength & $290 \mathrm{~N} / \mathrm{mm}^{2}$ \\
\hline Strain & $46 \%$ \\
\hline
\end{tabular}

Table 3: Physical properties of RHA.

\begin{tabular}{|c|c|}
\hline Particulars & Properties \\
\hline Color & Grey \\
\hline Shape texture & Irregular \\
\hline Musicology & Non crystalline \\
\hline Particle size & $<45$ micron \\
\hline Appearance & Very fine \\
\hline
\end{tabular}

Table 4: Chemical composition of RHA (\%).

\begin{tabular}{|c|c|}
\hline Particulars & Properties \\
\hline $\mathrm{SiO}_{2}$ & 93.8 \\
\hline $\mathrm{K}_{2} \mathrm{O}$ & 0.12 \\
\hline
\end{tabular}




\begin{tabular}{|c|c|}
\hline Loi & 3.37 \\
\hline $\mathrm{CaO}$ & 0.89 \\
\hline $\mathrm{Na}_{2} \mathrm{O}$ & 0.28 \\
\hline $\mathrm{MgO}$ & 0.32 \\
\hline $\mathrm{Al}_{2} \mathrm{O}_{3}$ & 0.3 \\
\hline $\mathrm{TiO}_{2}$ & 0.1 \\
\hline
\end{tabular}

test at 28 days with their specimen in each case and cured in water tank completely immersed at ambient temperature until the age of testing. All the cube specimen were casted and de-molded after 24 hours of casting. The total numbers of specimen were 60 casted and tested for the average of three results.

\section{Results and discussion}

\section{Workability test for fresh concrete}

The concrete mix was designed as per IS 10262-2009 to achieve a target compression strength of $45 \mathrm{MPa}$. The human hair fiber were added at percentage variation of $0,0.75 \% 1.5 \%$ and $2.25 \%$ by weight of cement and different percentage of RHA at variation of $0,5,10,15$ and $20 \%$ by weight in M 45 grade concrete and the result was compared to medium grade controlled concrete .Casting and testing of cubical specimen of size $150 \mathrm{~mm} \times 150 \mathrm{~mm}$ x 150mm for compressive strength was done as per IS 516:1959 specification. Compressive strength test was performed on cube

Slump test were carried out as per specification provided in IS- 1199: 1959 to study the workability of fresh concrete. From the Figure 1 it has been observed that the workability of concrete has been reduced constantly with the increase in the percentage of human hair in concrete. The reduction was slightly till $1.5 \%$ age of hair fibers but dropped suddenly, therefore 1.5 is the maximum percentage of human hair fiber was found to be provided a good workable concrete. The slump for the mixes was in the range of 92 to $145 \mathrm{~mm}$ in this study.

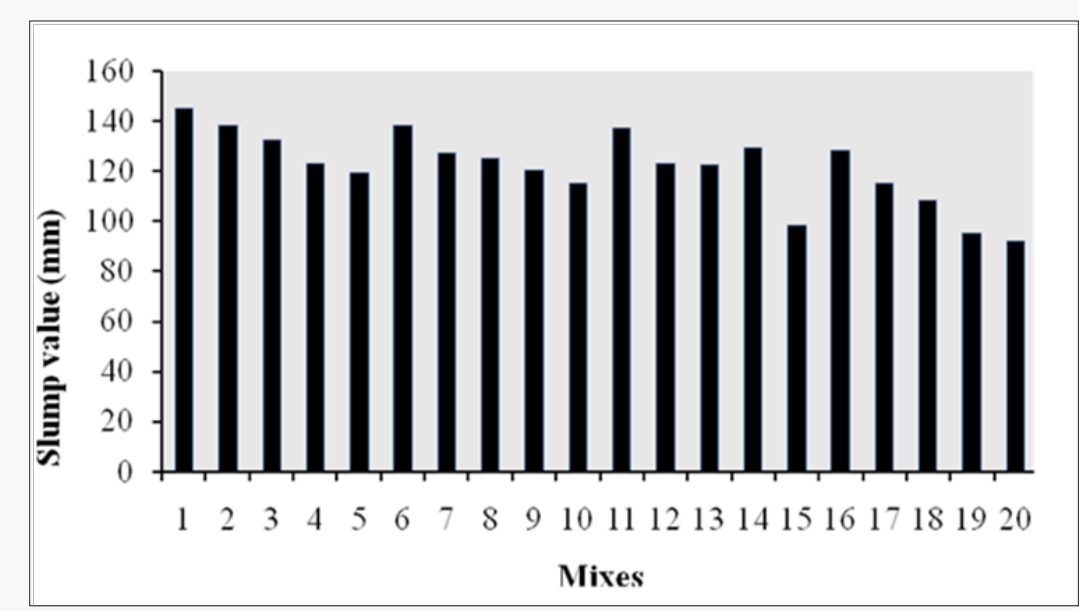

Figure 1: Graphical representation of the slump values of all the mixes.

\section{Compressive Strength test on harden concrete}

The test was conduct as per IS 516-1959 and the specimen were placed on the bearing surface of CTM of capacity $2000 \mathrm{KN}$.
A uniform rate of loading was applied till the failure of the cube. The maximum load was noticed and the compressive strength was determined and average of the three results was reported.

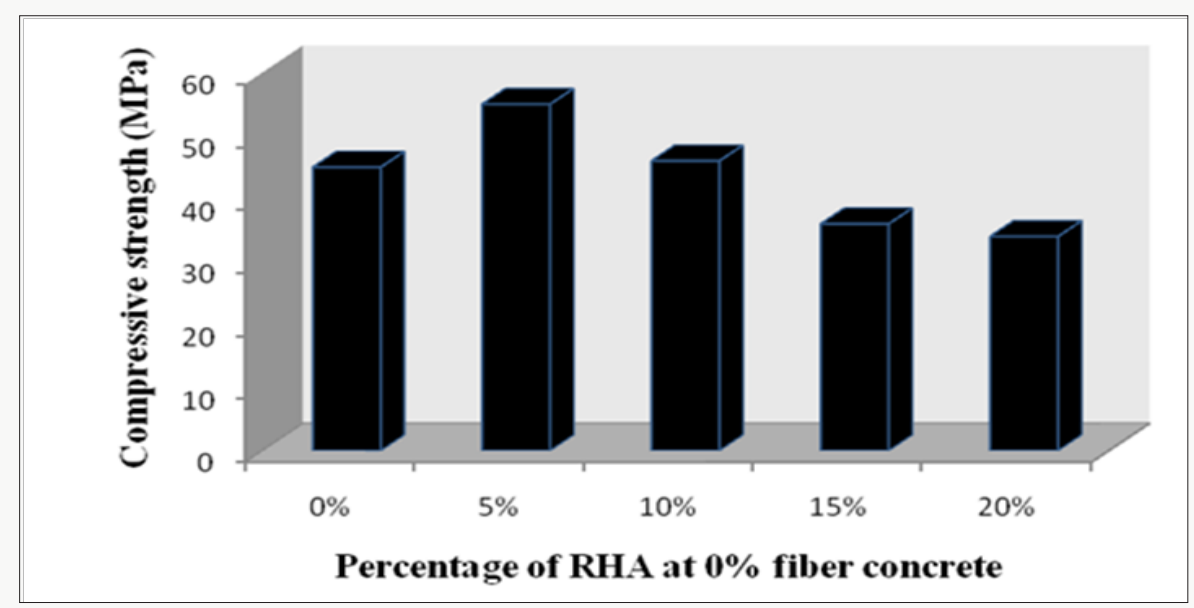

Figure 2: Effect of RHA at $0 \%$ human hair fiber. 


\section{Effect of different \% of RHA on human hair fiber concrete}

From the Figures 2-5 it is observed that after addition of different percentage of RHA in the controlled concrete at zero percentage of human hair, there is a gain in compressive strength about $22 \%$ at $5 \%$ of RHA and slightly higher at $10 \%$ in addition of RHA as compared to controlled concrete, further its decreases to the original value of compressive strength of control concrete at the percentage rice husk ash replacement level increases with cement. From fig. 2 it may be noted that the 5\% Rice husk ash mix is greater than the control mix by $22.2 \%$ but for Rice husk ash at 10,15 and $20 \%$ replacement level the compressive strength decreases by 19.5, 52.72 and $61.76 \%$ with 5\% RHA. In Figure 3 the compressive strength is greater at $5 \%$ RHA by $28.9 \%$ at $0 \%$ Rice husk ash strength with $0.7 \%$ human hair fiber. Similarly for the next two series in Figure 4 \& 5 the compressive strength increases at $5 \%$ Rice husk ash content by 25.6 and $18.9 \%$ than that of $0 \%$ RHA.

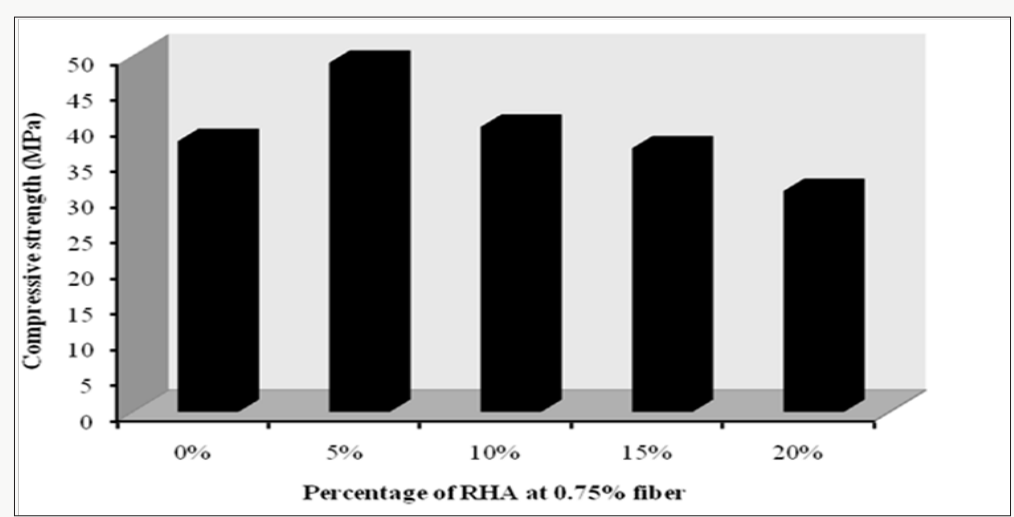

Figure 3: Effect of RHA at $0.75 \%$ human hair fiber.

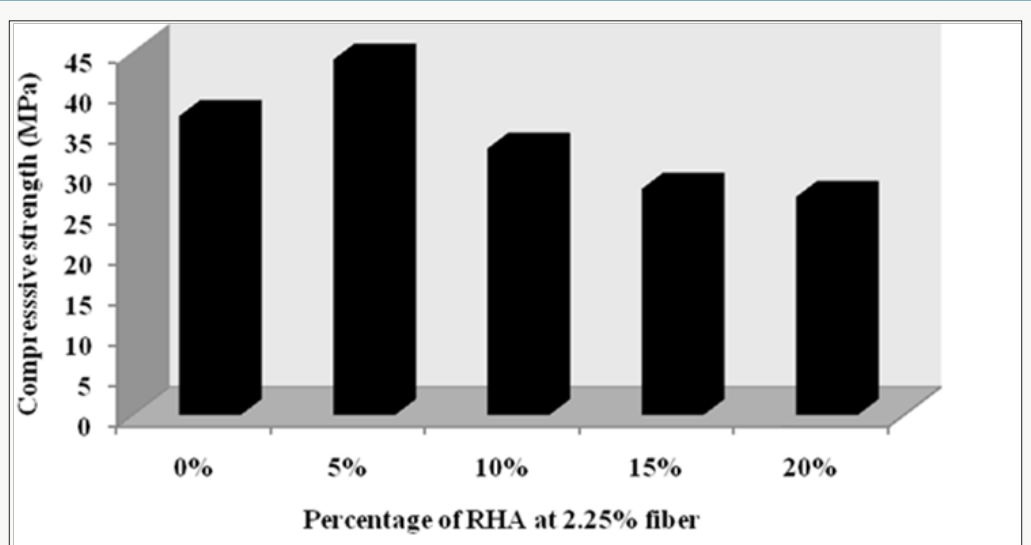

Figure 4: Effect of RHA at 1.5\% human hair fiber

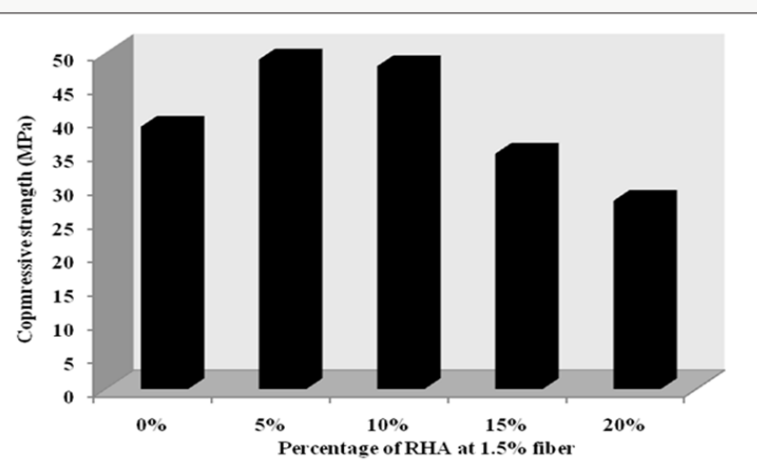

Figure 5: Effect of RHA at 2.25\% fiber.

\section{Effect of different percentages of human hair fiber on RHA mixes}

The different ratios of human hair fiber used are $0,0.75,1.5$ and $2.25 \%$ and compared with the controlled concrete. In compression to controlled concrete compressive strength is increased after addition of human hair fibers. It is observed that at 0\% RHA the control mix have highest compressive strength than the mixes at $0.75,1.5$ and $2.25 \%$ human hair fiber by $18.42,15.3$ and $21.6 \%$. The compressive strength with 5\% RHA at $0 \%$ human hair fiber is more than that of $0.75,1.5$ and $2.25 \%$ human hair by $12.24,12.24$ and $25 \%$. Further the compressive strength with $10 \%$ RHA at $1.5 \%$ human hair fiber is more than that of $0 \%$ human hair fiber by $4.34 \%$ and the compressive strength with 15\% RHA at $0.75 \%$ human hair fiber is more than that of $0 \%$ fiber by $2.85 \%$. Therefore Human hair fiber can be added up to $1.5 \%$ in the concrete as after this the compressive strength starts decreasing. The optimum replacement for Rice husk ash is $10 \%$ while for human hair it is $1.5 \%$ by weight of cement. During the compressive testing of human hair fiber reinforced concrete cubes specimens it is also noticed that crack formation and propagation of cracks are very much reduces and only hairs line cracks were found in the specimens. As the rice husk 
ash and human hair fibers is a waste material there for its reduces the cost of construction and effectively managed to be utilised in fiber reinforced construction [8-13].

\section{Conclusion}

Based on experimental test result on concrete the following conclusions are as follows.

a) The workability of concrete decreases as the replacement of cement by rice husk ash increase. Further during the mixing of human hair fiber in the concrete to achieve the good workability, there is a balling and lumps of hair fibers were notice at and above $1.5 \%$ of human hair fibers were used .

b) In replacement range of $0-20 \%$ rice husk ash, the compressive strength of concrete increases at $5 \%$ Rice husk ash for the second mix with $0,0.75 \& 1.5 \%$ human hair fiber. It increases by $22.2,28.9 \& 25.64 \%$ respectively than $0 \%$ Rice husk ash content.

c) There is a remarkable increment in the addition of $1.5 \%$ human hair fiber in compressive strength in all the mixes. The compressive strength of concrete increases with 0.75 and 1.5\% of human hair fiber at 10 and 15\% Rice husk ash content by $4.34 \& 2.85 \%$.

d) There has been a gradual increase in the compressive strength up to $1.5 \%$ of human hair fiber and the optimum replacement level of Rice Husk Ash is found to be to $10 \%$ for M45 grade of concrete after which the strength starts decreasing.

\section{References}

1. VM Nila, KJ Raijan, A Susmitha, B Riya, NR Davis (2015) Human hair as fiber reinforcement in concrete: An alternative method of hair waste management and its applications in civil constructions. International journal of current research 7(10): 21205-21210.
2. TN Kumar, K Goutami, J Aditya, K Kavya, VR Mahendar, et al. (2015) An experimental study on mechanical properties of human hair fiber reinforced concrete (M-40 grade).Journal of mechanical and Civil Engineering 12: 65-75.

3. MS Kulkarni, PG Mirgal, PP Bodhale, SN Tande (2014) Effects of rice hush ash on properties of concrete .Journal of Civil Engineering and Environmental Technology p. 26-29.

4. AS Kanagalakshmi, J Caroline Saro, V Jayashree (2015) Impact of Using RHA and CD in Replacement of Cement for Mix. International Journal of Computational Engineering Research 5(2): 1-10.

5. Tomas U, Ganiron (2014) Effects of Human Hair Additives in Compressive Strength of Asphalt Cement Mixture. International Journal of Advanced Science and Technology 67: 11-19.

6. D Jain, A Kothari (2012) Hair Fibre Reinforced Concrete. Research Journal of Recent Sciences 1: 128-132.

7. S Ahmad, F Ghani, JN Akhtar, M Hasan (2009) Use of waste human hair as a fiber reinforcement in concrete. Proceeding International Symposium on innovation and sustainability of structures in Civil Engineering held at Guangzhou Chaina

8. A Kumar (2014) A study on mechanical behaviour of hair fiber reinforced epoxy composites. National Institute of Technology Rourkela p. 17.

9. A. kumar, K Mohant, D Kumar, Om Parkash (2012) Properties and Industrial Applications of Rice husk: A review. International Journal of Emerging Technology and Advanced Engineering 2(10): 86-89.

10. C Marthong (2012) Effect of Rice Husk Ash (RHA) as Partial Replacement of Cement on Concrete Properties. International Journal of Engineering Research \& Technology (IJERT) 1(6): 1-6.

11. Y Batebi, A Mirzagoltabar, SM Shabanian, S Fateri (2013) Experimental Investigation of Shrinkage of Nano Hair Reinforced Concrete. Journal of Babol Noshirvani University of Technology p. 68-72.

12. (2000) Code of practice- plain and reinforced concrete. Bureau of Indian Standard, New Delhi, India.

13. (2004) Recommended guidelines for concrete mix design. Bureau of Indian Standard, New Delhi, India.
This work is licensed under Creative Commons Attribution 4.0 License

To Submit Your Article Click Here: Submit Article

DOI: $10.32474 /$ TCEIA.2018.02.000126

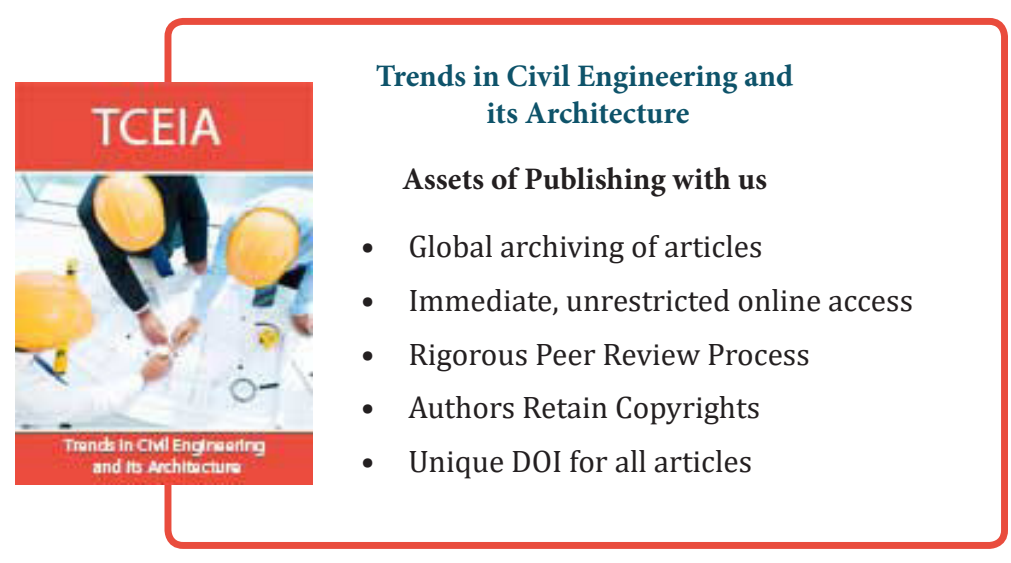

